\title{
Działania realizowane przez szkoły wyższe w ramach społecznej odpowiedzialności - dobre praktyki
}

\author{
Ewelina Pędziwiatr*, Agnieszka Czaplicka-Kotas**, Joanna Kulczycka***
}

\begin{abstract}
Streszczenie: Wdrażanie gospodarki opartej na wiedzy wpływa na zmiany w szkolnictwie wyższym. Istotnym elementem koncepcji jest wprowadzenie efektywnych mechanizmów zarządzania wiedzą, które prowadzą do konkurencyjności i innowacyjności uczelni na arenie polskiej oraz międzynarodowej. Dlatego też w obszarze działań strategicznych uczelni niezbędne jest prezentowanie nie tylko osiągnięć naukowych, ale i czynników społecznych, ekologicznych, ekonomicznych wspierających postrzeganie uczelni jako organizacji służącej otoczeniu. Relacje uczelni ze środowiskiem lokalnym mają niebagatelne znaczenie dla rozwoju regionu i podkreślają odpowiedzialność instytucji edukacyjnych w tym zakresie. Odpowiedzialność społeczna uczelni prezentowana jest w postaci raportów społecznych, zgodnie z koncepcją społecznej odpowiedzialności. Istnieje wiele dobrych praktyk opracowanych przez uczelnie zagraniczne, które interpretują społeczną odpowiedzialność uczelni w zróżnicowany sposób, w zależności od planów rozwojowych. Jednakże dotąd żadna polska uczelnia techniczna nie opracowała raportu społecznej odpowiedzialności. Celem artykułu jest zaprezentowanie wybranych działań zagranicznych uczelni podejmowanych w ramach społecznej odpowiedzialności oraz przedstawienie ścieżki raportowania społecznego w uczelni technicznej na przykładzie Akademii Górniczo-Hutniczej im. Stanisława Staszica w Krakowie (AGH), na podstawie analizy dokumentów. Autorzy dokonali przeglądu raportów społecznych uczelni zagranicznych publikowanych na stronach internetowych uczelni oraz Sprawozdania Rektora AGH z 2016 r. [Sprawozdanie, 2017]. Z analizy zaprezentowanej w artykule wynika, iż AGH wypracowała szereg dobrych praktyk z zakresu społecznej odpowiedzialności uczelni, które nie zostały dotychczas zaprezentowane $\mathrm{w}$ formie raportu społecznego.

Słowa kluczowe: CSR, społeczna odpowiedzialność uczelni, raportowanie społeczne, zrównoważony rozwój.
\end{abstract}

\section{Wprowadzenie}

Współczesne koncepcje na rzecz rozwoju gospodarczego państwa dążą do zintegrowania działań związanych z obszarami badań, innowacji i edukacji poprzez trójkąt wiedzy: badania - edukacja - innowacje [Leja, 2013]. Kluczową rolę $w$ tej koncepcji odgrywają uczelnie, których zadaniem jest tworzenie wiedzy i jej wdrażanie do gospodarki [Vadi, Haldma, 2010]. W ostatnich latach uczelnie dobrowolnie przyjmują na siebie także zobowiązania społeczne wykraczające poza obowiązki wynikające z przepisów prawa, przykładając większą uwagę do sze-

\section{* Ewelina Pędziwiatr}

Wydział Zarządzania

AGH Akademia Górniczo-Hutnicza

ul. Gramatyka 10, 30-067 Kraków

e-mail: ewelina.pedziwiatr.911@zarz.agh.edu.pl

** Agnieszka Czaplicka-Kotas

Wydział Zarządzania

AGH Akademia Górniczo-Hutnicza

ul. Gramatyka 10, 30-067 Kraków

e-mail: agnieszka.czaplicka.165@zarz.agh.edu.pl

*** Joanna Kulczycka

Katedra Zarządzania w Energetyce

Wydział Zarządzania

AGH Akademia Górniczo-Hutnicza

ul. Gramatyka 10, 30-067 Kraków

e-mail:jkulczyc@zarz.agh.edu.pl 
roko rozumianych problemów społecznych występujących w ich otoczeniu. Powyższy zakres działań uczelni wpisuje się w koncepcję trzech misji uczelni Clarka [Clark, 1998], która wskazuje, że współczesna uczelnia ma do wypełnienia trzy misje, z których pierwszą jest kształcenie, drugą - działalność naukowo-badawcza, a trzecią - kreowanie wzajemnych relacji $z$ otoczeniem. Zatem wypełnianie wszystkich trzech misji stanowi realizację postulatów społecznej odpowiedzialności uczelni. Działania społecznie odpowiedzialne uczelni wpisują się ponadto w europejskie plany strategiczne tj. europejski model polityki społecznej, wyrażony m.in. w celach Strategii „Europa 2020 Strategia na rzecz inteligentnego i zrównoważonego rozwoju sprzyjającego włączeniu społecznemu" [Europa 2020, 2010]. Priorytetami Strategii 2020 jest m.in. lepsze wykorzystanie przedsiębiorczości społecznej i biznesu odpowiedzialnego społecznie do realizacji celów społecznych i gospodarczych UE. Koncepcje ekonomii społecznej i społecznej odpowiedzialności mają w tym wymiarze charakter komplementarny, zmierzając do minimalizacji negatywnych skutków społecznych gospodarki wolnorynkowej [Płonka, 2015].

Ocena efektywności przeprowadzonych działań w powyższym zakresie i relacji nawiązanych $z$ interesariuszami może być prezentowana w formie tzw. raportów społecznych, opisujących relacje organizacji z otoczeniem $w$ aspekcie ekonomicznym, społecznym oraz środowiskowym.

W literaturze przedmiotu raportowaniu społecznemu przypisuje się przede wszystkim rolę narzędzia budującego relacje organizacji z jej interesariuszami zewnętrznymi oraz wewnętrznymi [Geryk, 2016; Sznajder, 2013]. Raportowanie społeczne ma również wymiar wizerunkowy, wspomaga reputację organizacji, pozwala wyróżnić się spośród konkurencji oraz wzmacnia pozycję na rynku [Dubigeon, 2006; Fijałkowska, 2012, s. 148; Jastrzębska, 2015].
Raportowanie społeczne uczelni technicznych pozwala budować relacje z kluczowymi interesariuszami, do których należy zaliczyć kadrę naukowo-badawczą, studentów oraz przedstawicieli przemysłu. Tymczasem obecnie żadna polska uczelnia techniczna nie opracowała raportu społecznego, prezentującego działania organizacji na rzecz interesariuszy w obszarze społecznej odpowiedzialności. W ostatnich latach pojawiły się jedynie raporty dotyczące poszczególnych wydziałów uczelni (m.in. Wydziału Informatyki i Komunikacji Uniwersytetu Ekonomicznego w Katowicach [Raport społeczny, 2014]). Brak jest wytycznych i krajowych dobrych praktyk dotyczących sporządzania raportów, a także nie zachodzi wymiana informacji pomiędzy uczelniami w zakresie pozyskiwania i opracowania danych do raportów społecznych. Jednocześnie działania organizacji międzynarodowych w tym obszarze (m.in. inicjatywa United Nations Global Compact), aktywność w zakresie raportowania uczelni zagranicznych oraz kroki podejmowane przez administrację rządową wskazują na potrzebę informowania o działaniach na rzecz interesariuszy zgodnie z koncepcją Społecznej Odpowiedzialności Biznesu (ang. Corporate Social Responsibility, CSR). Dnia 16 listopada 2017 r., z inicjatywy Zespołu ds. CSR i Kontaktów z Interesariuszami w Ministerstwie Rozwoju, 23 polskie uczelnie podpisały Deklarację Społecznej Odpowiedzialności Uczelni. Deklaracja w 12 punktach podejmuje zagadnienie organizacji pracy wspierającej promowanie idei społecznej odpowiedzialności, implementacji projektów badawczo-wdrożeniowych sprzyjających rozwiązywaniu problemów społecznych, ograniczania negatywnego wpływu na środowisko oraz realizacji działań przyczyniających się do rozwoju społecznej odpowiedzialności i relacji z interesariuszami [Deklaracja, 2017].

W świetle ostatnich działań propagujących ideę CSR w polskich uczelniach oraz braku raportów CSR polskich uczelni wskazana jest analiza dobrych praktyk $w$ tym obszarze 
zarówno na gruncie polskim, jak i międzynarodowym, a także wskazanie, w oparciu o uzyskane informacje, kierunków opracowania raportu społecznego polskiej uczelni.

W pracy dokonano przeglądu literatury, aktów prawnych oraz raportów w aspekcie koncepcji społecznej odpowiedzialności uczelni. W kolejnym rozdziale zawarto dobre praktyki w zakresie realizacji postulatów społecznej odpowiedzialności uczelni zagranicznych, a następnie omówiono implementowanie założeń tej koncepcji na uczelniach technicznych na przykładzie AGH. W podsumowaniu podkreślono rolę raportów społecznej odpowiedzialności w zrównoważonym rozwoju otoczenia bliższego oraz dalszego uczelni.

\section{Koncepcja społecznej odpowiedzialności uczelni}

Społeczna odpowiedzialność biznesu (ang. Corporate Social Responsability, CSR) jest zagadnieniem multidyscyplinarnym, rozważanym w aspekcie socjologicznym, filozoficznym, ekonomicznym, środowiskowym szczególnie w badaniach poświęconych zarządzaniu strategicznemu [Koneczna, 2014]. CSR to podejście do organizacji pozwalające określić, w jaki sposób jest ona zarządzana, jak realizuje swoją misję, jakimi kieruje się wartościami, jakie ma relacje z interesariuszami. Pierwotnie CSR dotyczył relacji podmiotów gospodarczych z udziałowcami i podmiotami współpracującymi [Bowen, 1953, s. 6]. Wraz z rozwojem koncepcji, w literaturze przedmiotu pojawiły się nowe komentarze podkreślające wagę otoczenia organizacji, a tym samym jej oddziaływania na społeczeństwo [McGuire, 1963; Freederick, 1960]. Współcześnie koncepcja CSR została spopularyzowana i zdefiniowana przez m.in. Komisję Europejską, Bank Światowy, Organizację Narodów Zjednoczonych oraz Międzynarodową Organizację Standaryzacyjną. Rozróżnia się także definiowanie działań na rzecz społecznej odpowiedzialności przez Organizację
Współpracy Gospodarczej i Rozwoju (OECD), która zamiast terminu CSR stosuje odpowiedzialne prowadzenie biznesu (ang. Responsible Business Conduct, RBC) [OECD, 2011]. CSR jest bardzo szerokim pojęciem, dlatego też każda z instytucji zdefiniowała koncepcję w inny sposób, np. jako narzędzie zapewniające przewagę konkurencyjną [Odnowiona strategia, 2011] lub jako podstawową strategię na rzecz zrównoważonego rozwoju [Global Compact, 2007].

CSR postrzegany pierwotnie w kontekście organizacji działających dla zysku zapoczątkował powstanie koncepcji społecznej odpowiedzialności dla innych podmiotów, nie działających dla zysku, m.in.: organizacji pozarządowych, podmiotów systemu ochrony zdrowia, podmiotów systemu edukacji [Kowalski, 2016]. Rozwijana jest także koncepcja Społecznej Odpowiedzialności Uczelni (ang. University Social Responsability, USR), w rozumieniu której uczelnia jest istotną formą organizacji działającej w społeczeństwie [Shek, Yuen-Tsang, Ng, 2017a]. Cybal-Michalska [2015, s. 90] podkreśla, iż rozważając koncepcję społecznej odpowiedzialność w kontekście uczelni należy pamiętać o głównym celu, tj. kształceniu oraz badaniach naukowych, co odróżnia ją od ośrodków biznesowych. Vasilescu wraz z współpracownikami [2010, s. 4178-4180] w efektywnej implementacji USR zaznaczają rolę zaangażowanego społeczeństwa obywatelskiego posiadającego wartości moralno-etyczne w tworzenie społeczności akademickiej, działającej na rzecz społeczności lokalnej oraz promowania myśli ekologicznej, tym samym wpływając na lokalny i globalne zrównoważony rozwój. Vallaeys [2013] zaznaczył rolę współodpowiedzialności oraz współpracy interesariuszy na rzecz ciągłego doskonalenia USR. Głównym celem wdrażania strategii na rzecz społecznej odpowiedzialności w jednostkach z otoczenia biznesowego oraz akademickiego jest pozytywne oddziaływanie na społeczeństwo.

W dobie globalizacji uczelnie zmieniły swój charakter, w szczególności ze względu 
na zwiększenie mobilności studentów oraz popyt na pracowników posiadających specjalistyczną, zamiast kompleksowej, wiedzę. Zmieniło się również postrzeganie uczelni jako dobra publicznego na rzecz dobra prywatnego spełniającego oczekiwania indywidualnych jednostek [Lo et al., 2017]. W konsekwencji należy poszukiwać pozaprawnego uzasadnienia opracowania raportów społecznych uczelni. Realizowanie postulatów społecznej odpowiedzialności i informowanie o podejmowanych działaniach ma przede wszystkim wpływ na uzyskanie przez uczelnię przewagi konkurencyjnej oraz stanowi element działań o charakterze wizerunkowym i promocyjnym, co wiąże się z budowaniem marki uczelni [Duś, 2008].

Działalność uczelni upowszechniająca koncepcję CSR przyczynia się także do wzrostu świadomości studentów co do konieczności postrzegania gospodarki w kontekście wyzwań i celów społecznych. Podnoszenie kompetencji interesariuszy uczelni w obszarze społecznej odpowiedzialności pozytywnie oddziałuje tym samym pośrednio na sektor ekonomii społecznej, który w osobach absolwentów zyskuje potencjalne wykwalifikowane kadry. Raportowanie jest także okazją do zaangażowania akademickiej społeczności, stanowi regularny przegląd aktywności jednostek i podmiotów działających w obrębie uczeni oraz pozwala zaplanować dalsze działania z uwzględnieniem potrzeb interesariuszy.

\section{Dobre praktyki w zakresie realizacji postulatów społecznej odpowiedzialności uczelni}

Działania uczelni w zakresie społecznej odpowiedzialności oraz będące ich konsekwencją raportowanie społeczne nie są realizowane według ogólnie przyjętych wytycznych. Najpowszechniej stosowanymi obecnie wskaźnikami w raportowaniu społecznym są wytyczne Global Reporting Initiative (GRI). Celem Ramowych Zasad Raportowania GRI jest stworzenie ogólnie przyjętych ram dla raportowania ekonomicznych, środowiskowych oraz społecznych aspektów funkcjonowania organizacji. W 2013 r. GRI opublikowało najnowsze i najpełniejsze wytyczne raportowania społecznego G4 [GRI Standards, 2017]. Zasad można używać w całości, ale organizacja może również użyć tylko wybrane wskaźniki GRI lub nawet części ich zawartości, aby zaraportować odpowiednie, specyficzne informacje.

O ile zasady GRI dają pewne wytyczne w zakresie raportowania społecznego, o tyle już zakres działań w obszarze społecznej odpowiedzialności jest decyzją organizacji. Działaniem na rzecz promowania koncepcji społecznej odpowiedzialności na uczelni jest międzynarodowa sieć University Social Responsibility Network (USRN) utworzona w 2015 r. i grupująca 23 uczelnie z całego świata. Celem sieci jest stworzenie platformy wymiany informacji oraz zacieśnienia współpracy wspierającej interdyscyplinarne projekty z zakresu problematyki USR [Shek, Yuen-Tsang, Ng, 2017b]. W konsekwencji, w celu realizacji postulatów społecznej odpowiedzialności uczelni i wdrożenia raportowania społecznego wskazany jest przegląd dobrych praktyk w tym zakresie.

Szczególnie interesujące są doświadczenia uczelni notowanych w czołówce Akademickiego Rankingu Uniwersytetów Świata, tzw. Rankingu Szanghajskiego [Academic Ranking of World Universities, 2017], i mających wieloletnie doświadczenie $\mathrm{w}$ raportowaniu społecznym. Analiza działań i raportowania Uniwersytetu Harvarda, Yale i Uniwersytetu Stanforda, będących od lat w czołówce światowego rankingu uczelni, wskazuje, że społeczna odpowiedzialność przejawia się przede wszystkim w realizacji działań na rzecz zrównoważonego rozwoju, co stanowi element aspektu środowiskowego CSR. Działania Uniwersytetu Harvarda realizowane są pod hasłem "green Harvard" i prezentowane na stronie www.green.harvard.edu. Koncepcja CSR realizowana jest poprzez inwestycje 
w infrastrukturę uczelni (wymiana okien, instalacje paneli solarnych, budownictwo pasywne w obrębie kampusu), działalność edukacyjną (przedmiot CSR jako obowiązkowa część programu studiów w Harvard Business School), czy aktywności popularyzujące zrównoważone wykorzystanie zasobów (konkurs dla pracowników związany z oszczędzaniem energii, promocja transportu rowerowego, wskazówki dla studentów zgodne z koncepcją zero waste) ${ }^{1}$.

Uniwersytet Yale realizuje działania w oparciu o wieloletni Plan Zrównoważonego Rozwoju (Sustainability Plan), którego realizacja obejmuje wszystkie aspekty działalności uczelni. Elementem Planu jest wymóg uwzględniania w procedurach zamówień publicznych warunku zrównoważonego rozwoju, w zakresie dostosowanym do przedmiotu zamówienia, a także szczegółowo opisane zasady segregacji odpadów obowiązujące studentów mieszkających w obrębie kampusu uniwersyteckiego².

Uniwersytet Stanforda podejmuje szereg działań edukacyjnych i informacyjnych w obszarze zrównoważonego rozwoju. W 2016 r. przygotowano siedmiominutowy film, w którym przedstawiciele studentów, wykładowców i pracowników administracyjnych opowiadają o codziennych działaniach, jakie podejmują na rzecz zrównoważonego rozwoju. Uniwersytet jest także światowym liderem w zakresie edukacji w obszarze społecznej odpowiedzialności oferując studentom ponad 500 kursów o tej tematyce. Stanford stosuje ponadto system zachęt finansowych w postaci premii finansowych dla pracowników deklarujących korzystanie z transportu publicznego i rowerowego ${ }^{3}$. W postulaty CSR wpisuje się także inicjatywa Uniwersytetu w Ohio, w którego strukturach działa Biuro Zrównoważonego Rozwoju. Biuro odpowiedzialne jest za wdrażanie i monito- rowanie realizacji Planu Zrównoważonego Rozwoju (Ohio University Sustainability Plan). Poza biurem w strukturze uczelni działa również forum wymiany informacji i poglądów w obszarze CSR, którego wyniki prac są uwzględniane w treści cyklicznych raportów społecznych. Spotkania SOUL (Sustainable Ohio University Leaders) odbywają się 10 razy do roku i otwarte są dla wszystkich interesariuszy (pracownicy, studenci, podmioty współpracujące z uniwersytetem).

Źródłem dobrych praktyk są także działania podejmowane na europejskich uczelniach. W zakresie działań skierowanych do studentów, Uniwersytet Cambridge od 2000 r. realizuje kursy o tematyce CSR oferowane studentom kierunków technicznych. Kursy prowadzone są przez Centrum Zrównoważonego Rozwoju (CUED, Centre for Sustainable Development), które prowadzi również badania w zakresie zrównoważonego wykorzystania surowców, wody, gospodarki o obiegu zamkniętym oraz metod ewaluacji obszarów związanych z CSR ${ }^{4}$. Na Uniwersytecie Edynburskim zagadnienia CSR stanowią tematykę kursów akademickich, ale są prezentowane również jako potencjalne ścieżki kariery dla absolwentów. Studenci informowani są o możliwościach zatrudnienia w branżach wykazujących zapotrzebowanie na specjalistów z obszaru zrównoważonego rozwoju oraz posiadających umiejętności w zakresie opracowania raportów społecznych ${ }^{5}$. Dobre praktyki w zakresie wdrażania CSR stanowią także działania Uniwersytetu Oxfordzkiego skierowane do lokalnych społeczności, definiowane jako utrzymywanie dobrosąsiedzkich stosunków m.in. poprzez organizację popołudniowych kursów edukacyjnych dla dorosłych mieszkańców Oxfordu, program prezentacji eksperymentów naukowych czy udostępnianie obiektów uniwersyteckich do 
organizacji wydarzeń kulturalnych ${ }^{6}$. Podobne działania podejmuje również Uniwersytet Leicester. Uczelnia wsparła opracowanie miejskiego planu ochrony powietrza, organizuje bezpłatne kursy dla mieszkańców z zakresu pierwszej pomocy medycznej oraz realizuje program nauczania genetyki dla uczniów lokalnych szkół’

Powyższe przykłady aktywności uczelni wpisujących się w koncepcję społecznej odpowiedzialności pokazują, że działania w obszarze społecznej odpowiedzialności mają zróżnicowany charakter - od wysokonakładowych inwestycji w infrastrukturę uczelni, poprzez działania na rzecz lokalnych społeczności, aż po doraźne inicjatywy popularyzujące zrównoważony rozwój wśród studentów i pracowników. Wspólnym elementem strategii CSR wszystkich analizowanych uczelni jest natomiast powołanie jednostki koordynującej i inicjującej działania CSR oraz cykliczne raportowanie społeczne, w tym zamieszczanie informacji na stronie www uczelni. Poza wymienionymi w niniejszym artykule przykładami uczelnie prezentują w raportach społecznych szereg działań w obszarze środowiskowym, ekonomicznym i społecznym, które tworzą obraz organizacji odpowiedzialnych społecznie. Podstawą stworzenia raportu społecznego mogą być działania realizowane w ramach statutowej misji w obszarze edukacji, badań i rozwoju, bez konieczności wdrażania nowych aktywności. Pierwszy raport społeczny stanowi zatem przegląd dotychczasowych aktywności organizacji wpisujących się w koncepcję CSR oraz wskazanie ograniczeń oraz zagadnień, które wymagają rozwinięcia w kolejnych raportach. Analizę w tym zakresie przedstawiono w kolejnym rozdziale.

\section{Uwarunkowania opracowania raportu społecznego przez uczelnię techniczną w Polsce na przykładzie Akademii Górniczo-Hutniczej w Krakowie}

Akademia Górniczo-Hutnicza w Krakowie w 2017 r. przystąpiła do sieci współpracy United Nations Global Compact zrzeszającej ponad 9000 największych firm i 5000 instytucji z całego świata, które wspólnie dyskutują z rządami i instytucjami naukowymi na szczeblu krajowym i ponadnarodowym o zrównoważonym rozwoju. W związku z przystąpieniem do sieci, AGH jest zobowiązane do przedłożenia pierwszego raportu społecznego do 2019 r., co stało się impulsem do analizy działań uczelni pod kątem realizacji postulatów społecznej odpowiedzialności. Zgodnie z dobrymi praktykami i literaturą przedmiotu dokonano analizy aktywności AGH w trzech aspektach: ekonomicznym, środowiskowym i społecznym.

Aspekt ekonomiczny zrównoważonego rozwoju obejmuje działania i postawy wpływające na konkurencyjność analizowanego podmiotu oraz działania zmierzające do pozyskania środków finansowych umożliwiających realizację celów instytucji, w tym szeroko pojętą współpracę międzynarodową. Analizując działalność AGH pod kątem raportowania społecznego o realizacji postulatów zrównoważonego rozwoju w obszarze ekonomicznym świadczą przede wszystkim działania związane z komercjalizacją wyników badań naukowych i pozyskiwaniem środków zewnętrznych na działalność dydaktyczną i rozwojową, w tym przedsięwzięcia innowacyjne. Raportując w tym obszarze pod uwagę należy wziąć zagadnienia związane z ochroną własności intelektualnej, transferem technologii oraz współpracą z podmiotami gospodarczymi w sektorach związanych z kierunkami kształcenia i badań AGH. Wykaz obszarów działalności uczelni potwierdza- 
jący społeczną odpowiedzialność w aspekcie ekonomicznym przedstawiono na rysunku 1.

\section{Rysunek 1. Ekonomiczne aspekty społecznej odpowiedzialności AGH}

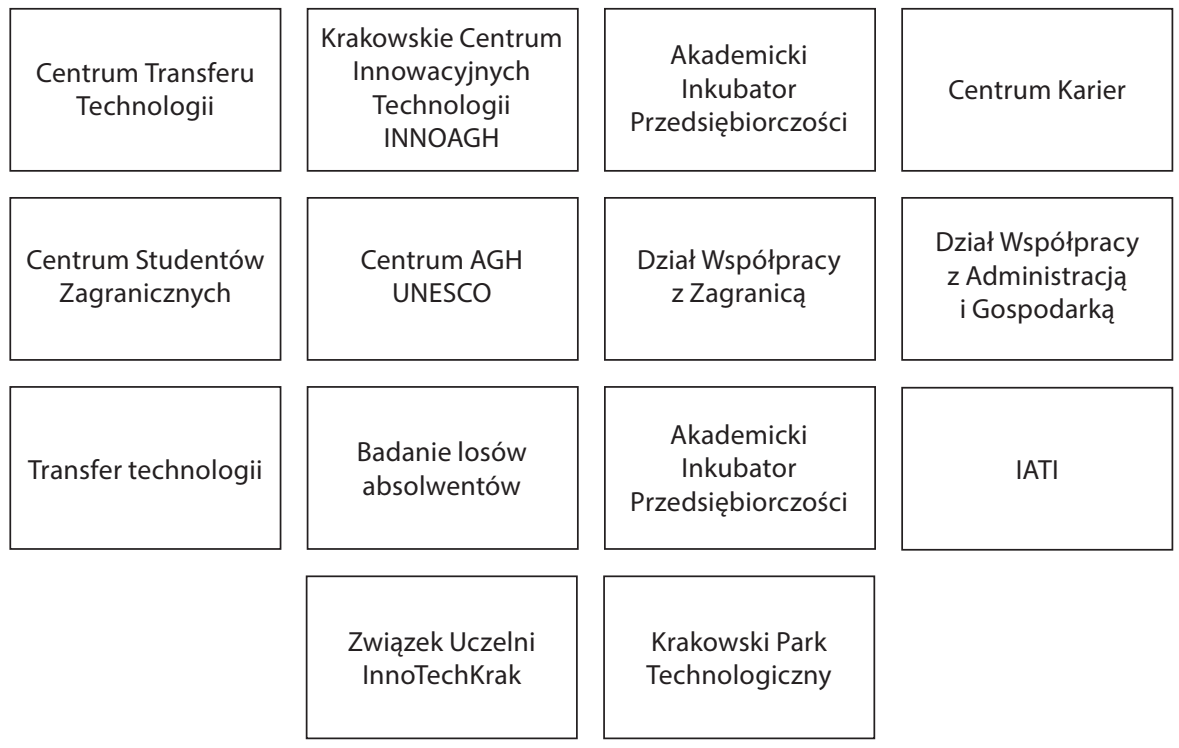

Źródło: opracowanie własne.

Aspekt ekonomiczny w największym stopniu, spośród trzech wymiarów społecznej odpowiedzialności, kształtowany jest w oparciu o relację uczelni z podmiotami zewnętrznymi. Społeczną odpowiedzialność w tym zakresie kształtują zatem relacje z przedsiębiorstwami, wpływające na rynek pracy oraz związane z komercjalizacją wyników badań naukowych.

Realizacja postulatów społecznej odpowiedzialności przekłada się na relacje uczelni z interesariuszami, m.in. ze stowarzyszeniami, fundacjami, zrzeszeniami działającymi przy AGH, ale również poprzez uzyskane wyniki w zakresie efektów kształcenia, a także zarządzanie zasobami ludzkimi. Bardzo ważnym czynnikiem wpływającym na otoczenie wewnętrzne i zewnętrzne uczelni są relacje $z$ pracownikami m.in. organizowane szkolenia, projekty edukacyjne, świadczenia socjalne, oferty kulturalno-rozrywkowe jak również wiele innych inicjatyw. Działania te mają zatem zróżnicowany charakter, co jest pochodną zróżnicowanych grup interesariuszy uczelni, co przedstawiono na rysunku 2.

Przykład AGH wskazuje, że aspekt społeczny CSR realizowany może być zarówno w wymiarze zinstytucjonalizowanym, jak również dotyczyć postaw, standardów zachowań regulowanych przez kodeksy etyki.

Analiza dobrych praktyk wskazuje na duże znaczenie aspektu środowiskowego w raportowaniu społecznej odpowiedzialności. Na przestrzeni ostatnich lat opracowano wiele dokumentów strategicznych na rzecz ochrony środowiska, m.in. strategię zrównoważonego rozwoju i gospodarki o obiegu zamkniętym oraz zasad czystej produkcji, tym samym wpływając na wzrost świadomości ekologicznej społeczeństwa. Świadomość ta przekłada się na presję wywieraną na podmioty gospodarcze - społeczeństwo 
wymaga od przedsiębiorców stosowania praktyk bezpiecznych dla środowiska. Interesariusze coraz częściej interesują się wyrobami i usługami spełniającymi coraz wyższe standardy środowiskowe. Sytuacja ta znajduje swoje odzwierciedlenie w raportowaniu społecznym, które stanowi dokumentację wysiłków podejmowanych na rzecz wdrażania systemowych metod osiągania coraz wyższych standardów w obszarze zrównoważonego rozwoju. Działania w obszarze zrównoważonego rozwoju podejmowane przez AGH zaprezentowano na rysunku 3.

\section{Rysunek 2. Społeczny aspekt społecznej odpowiedzialności AGH}

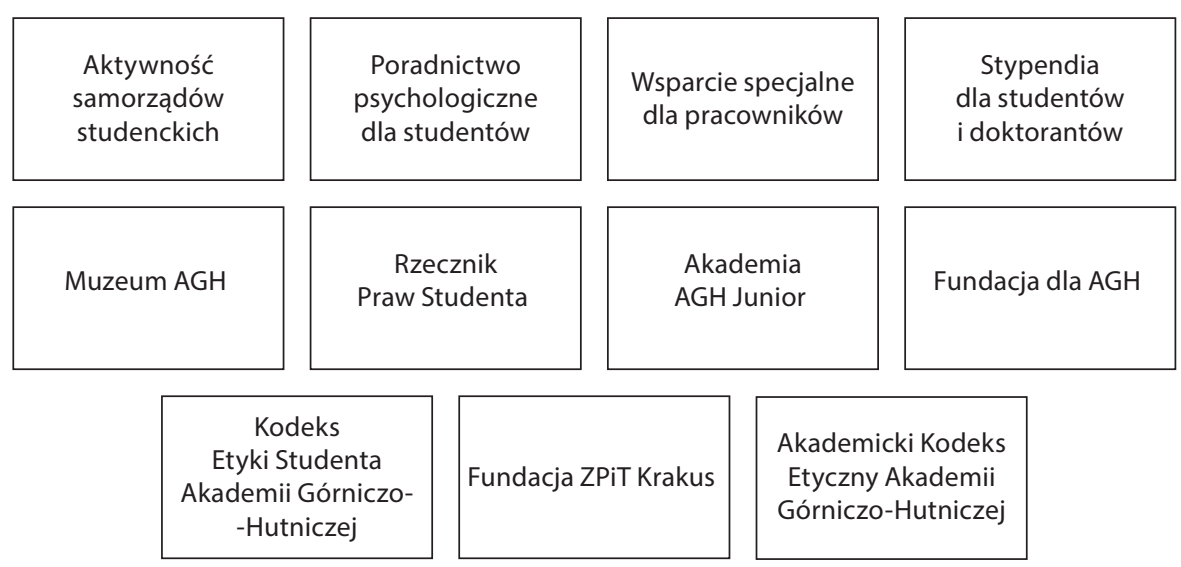

Źródło: opracowanie własne.

\section{Rysunek 3. Środowiskowy aspekt społecznej odpowiedzialności AGH}
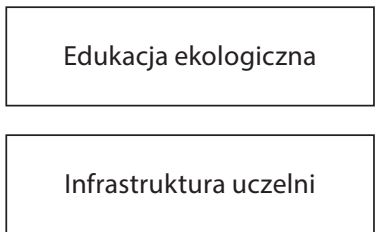

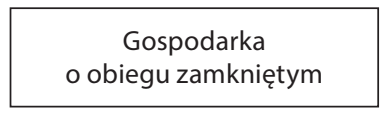

Zmniejszenie zużycia energii

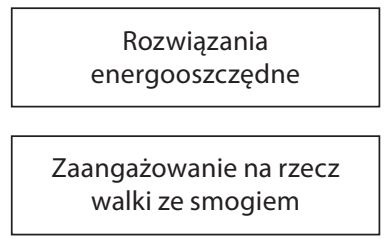

Źródło: opracowanie własne.

Wskazane działania w ramach różnych aspektów społecznej odpowiedzialności mają charakter interdyscyplinarny - te same działania mogą bowiem realizować łącznie postulaty wskazywane w obszarze ekonomicznym i społecznym, czy ekonomicznym i środowiskowym (np. działania zmierzające do ograniczenia kosztów eksploatacyjnych poprzez wykorzystanie odnawialnych źródeł energii, czy realizacja projektów dofinansowanych ze źródeł zewnętrznych wdrażających prośrodowiskowe rozwiązania). W kon- sekwencji działania CSR uczelni wymagają współpracy pomiędzy wieloma jednostkami. W ramach struktury organizacyjnej Akademii Górniczo-Hutniczej działa 7 pionów odpowiedzialnych za różne aspekty działalności uczelni. Na rysunku 4 wskazano zakres kompetencji poszczególnych jednostek i odpowiadające ich działalności aspekty społecznej odpowiedzialności. Podział wskazuje na dużą interdyscyplinarność działań poszczególnych pionów. Zgodnie z przedstawionym podziałem należy zauważyć, że wszelkie działania 
podejmowane przez jednostki organizacyjne Uczelni mają wymiar społeczny - działania prośrodowiskowe przekładają się bowiem na realizację postulatów społecznych związanych z poprawą jakości pracy i studiowa- nia. Podobne rezultaty mają przedsięwzięcia o charakterze ekonomicznym, umożliwiające wdrożenie i finansowanie innowacji oraz wpływających na wzrost środków, którymi dysponuje Uczelnia.

\section{Rysunek 4. Rodzaje działań z zakresu CSR podejmowanych przez piony AGH}

\begin{tabular}{|l|c|c|c|}
\hline \multicolumn{1}{|c|}{ Pion } & Aspekt środowiskowy & Aspekt ekonomiczny & Aspekt społeczny \\
\hline Proces Kształcenia & $\times$ & & $\times$ \\
\hline Pion Spraw Studenckich & & $\times$ & $\times$ \\
\hline Pion Nauki & & $\times$ & $\times$ \\
\hline Pion Współpracy & $\times$ & $\times$ & $\times$ \\
\hline Pion Ogólny & $\times$ & $\times$ & $\times$ \\
\hline Pion Kanclerza & $\times$ & $\times$ & $\times$ \\
\hline Pion Biura Rektora & & $\times$ & $\times$ \\
\hline
\end{tabular}

Źródło: opracowanie własne.

W oparciu o analizę ogólnodostępnych danych w trzech wskazanych aspektach można stwierdzić, że AGH w Krakowie gromadzi i upublicznia informacje będące podstawą do raportowania społecznego według przyjętych standardów i dobrych praktyk w zakresie społecznej odpowiedzialności. Przeprowadzona analiza jest pierwszym etapem opracowania raportu społecznego. W oparciu o dobre praktyki oraz dorobek naukowy w zakresie realizacji działań CSR i tworzenia raportów społecznych wyodrębnić można kolejne etapy prac prowadzących do powstania raportu społecznego polskiej uczelni.

Identyfikacja i zebranie danych o aktywności uczelni umożliwia dokonanie przeglądu wskaźników GRI pod kątem możliwości pozyskania ustandaryzowanych danych i raportowania za pomocą zdefiniowanych w Zasadach wskaźników. Przegląd ten powinien być realizowany $w$ ścisłej współpracy z jednostkami uczelni odpowiedzialnymi za gromadzenie danych (m.in.: pion administracyjny, zamówień publicznych, kwestura, dział kadr). Kolejnym krokiem jest dobór wskaźników i obszarów, które zostaną przedstawione w raporcie, a następnie wprowadzenie jed- nolitych zasad raportowania dla wszystkich jednostek uczelni w celu uzyskania porównywalnych danych. Każdy z etapów prac nad raportem wymaga zaangażowania interesariuszy wewnętrznych i zewnętrznych uczelni. W początkowym etapie prac będą to przeważnie interesariusze wewnętrzni: jednostka odpowiedzialna za działania CSR uczelni, władze uczelni, pracownicy administracyjni i przedstawiciele władz wydziałów. Po ustaleniu zasad raportowania niezbędne jest zaangażowanie w tworzenie raportu społecznego szerszych grup interesariuszy, w tym przede wszystkim pracowników naukowych, studentów organizacji współpracujących z uczelnią poprzez przeprowadzenie badań wizerunkowych, warsztatów, wykładów upowszechniających zagadnienia CSR, spotkań informacyjnych oraz komunikację online, m.in. poprzez media społecznościowe.

Od 2011 r. w ofercie zajęć dydaktycznych znajdują się przedmioty przybliżające koncepcję społecznej odpowiedzialności biznesu. W ramach opracowania raportu społecznego wskazane jest zaangażowanie studentów w proces raportowania, w ramach zajęć dydaktycznych. 
Ostatnim etapem poprzedzającym publikację raportu jest określenie formuły prezentacji danych. Dobre praktyki w tym zakresie wskazują na możliwość opracowania wieloletniego planu zawierającego w diagnozie sytuacji wskaźniki raportowania społecznego, cyklicznego raportu społecznego lub przedstawienie zebranych danych $\mathrm{w}$ formie broszury, ulotki czy na stronie www uczelni. Forma prezentacji będzie każdorazowo pochodną przeprowadzonej analizy interesariuszy oraz strategii komunikacji uczelni. Publikacja raportu w przyjętej formie nie kończy procesu pozyskiwania i interpretacji danych. Jest to bowiem działanie ciągłe oraz wymagające podjęcia intensywnych działań na rzecz dotarcia do szerokich grup odbiorców, niezależnie od częstotliwości publikacji samego raportu.

\section{Podsumowanie}

Kluczowe w rozważaniu koncepcji społecznej odpowiedzialności w kontekście działalności szkół wyższych, jest ich nowa rola związana z kształceniem zgodnym z wymogami gospodarki. W dobie współczesnej globalizacji zmienia się system funkcjonowania otoczenia bliższego oraz dalszego uczelni, co wpływa bezpośrednio na kształtowanie społeczeństwa na szczeblu lokalnym, regionalnym oraz krajowym [Geryk, 2016]. W związku z tym w literaturze przedmiotu [Vallaeys, 2013; Wigmore-Álvarez, Ruiz-Lozano, 2012; Pędziwiatr, Czaplicka-Kotas, Kulczycka, 2018] oraz w niniejszym artykule podkreślona jest konieczność prezentowania działań społecznie odpowiedzialnych uczelni w aspekcie społecznym, ekonomicznym, środowiskowym, gdzie szkoła wyższa rozpatrywana jest w sposób dualny, tj. jako organizacja posiadająca wartości moralno-etyczne, kreująca społeczeństwo obywatelskie oraz organizacja rynkowa tworząca usługę edukacyjną istotną dla globalnego rozwoju. Wyniki badań [Wilson, 2016; Nejati et al., 2011] poka- zują, iż usystematyzowanie procedur raportowania społecznego przez uczelnie generowałoby wartość dodaną dla interesariuszy organizacji.

Pomimo rosnącej liczby podmiotów raportujących społecznie - zarówno podmiotów gospodarczych, działających dla zysku, jak również instytucji realizujących zadania w obszarze społecznym, naukowym, kulturalnym - żadna Polska uczelnia techniczna nie opracowała dotąd raportu w zakresie społecznej odpowiedzialności. Raportowanie społeczne uczelni wpisuje się tymczasem w obserwowane trendy i priorytety strategiczne w skali międzynarodowej i krajowej. Zagadnienie CSR jest przedmiotem debat, dyskusji i uzgodnień na forach organizacji międzynarodowych. Raporty społeczne opracowuje rosnąca liczba uczelni, w tym wszystkie notowane w czołówce Rankingu Szanghajskiego. Raporty w zakresie społecznej odpowiedzialności uczelni zagranicznych stanowią źródło dobrych praktyk przy opracowaniu założeń raportu społecznego polskiej uczelni. Realizacji postulatów społecznej odpowiedzialności i ich raportowaniu sprzyjają również działania w skali krajowej, m.in. podpisana 16.11.2017 r. Deklaracja Społecznej Odpowiedzialności Uczelni.

Akademia Górniczo-Hutnicza w Krakowie od lat podejmuje działania wpisujące się w koncepcję CSR i tym samym kwalifikujące się do raportowania społecznego w obszarze środowiskowym, ekonomicznym i społecznym. W oparciu o analizę ogólnodostępnych danych w obszarze społecznym, ekonomicznym i środowiskowym można stwierdzić, że Akademia Górniczo-Hutnicza w Krakowie gromadzi i upublicznia obecnie informacje będące podstawą do raportowania społecznego. Dane te mogą być podstawą do opracowania pierwszego raportu społecznego polskiej uczelni technicznej i stanowić mogą zbiór dobrych praktyk zarówno dla AGH przy przygotowaniu kolejnych cyklicznych raportów, jak również dla innych polskich szkół wyższych. 
Istotnym aspektem wymagającym dalszych badań jest zatem analiza nie tylko działań uczelni w danych obszarach społecznej odpowiedzialności, ale także analiza dotychczasowych raportów społecznych uczelni

\section{Literatura}

Academic Ranking of World Universities (2017). http://www.shanghairanking.com/.

Bowen H. (1953). The Social Responsibilities of Businessman. New York: Harper.

Clark B.R. (1998). Creating entrepreneurial universities: organizational pathways of transformation. Issues in Higher Education. New York: Elsevier Science Regional Sales.

Cybal-Michalska A. (2015). "Społeczna odpowiedzialność uczelni wyższych", Rocznik Lubuski, t. 41, cz. 2, s. 89-96.

\section{Deklaracja Społecznej Odpowiedzialności Uczelni (2017). Warszawa: Ministerstwo Rozwoju, http://www.miir.gov.pl/media/46898/Deklaracja_ sou.pdf.}

Dubigeon O. (2006). Legal Obligations and Local Practices in Corporate Social Responsibility, w: J. Allouche (red.), Corporate Social Responsibility, Vol. 1: Concepts, Accountability and Reporting (s. 254-283). New York: Palgrave Macmillan.

Europa 2020. Strategia na rzecz inteligentnego i zrównoważonego rozwoju sprzyjającego włączeniu społecznemu (2010). Komunikat Komisji Europejskiej, COM (2010) 2020 wersja ostateczna.

Fijałkowska J. (2012). „Społeczna odpowiedzialność wyzwaniem dla rachunkowości", Przedsiębiorczość i Zarządzanie, t. XIII, z. 1, s. 141-154.

Freederick W.C. (1960). "The Growing Concern Over Bussiness Responsibility", California Management Review, No. 2(4), s. 54-61.

Geryk M. (2016). „Zmiany funkcjonowania uczelni w polskim systemie szkolnictwa wyższego, czyli interesariusze mają głos", Przedsiębiorczość i Zarządzanie, t. 17, z. 4, cz. 1 Między teorią i praktyką zarządzania: dokonania, dylematy, inspiracje: nauka dla praktyki gospodarczej i samorządowej, s. 47-58.

Global Compact (2007). The principles for responsible management education. United Nations Global Compact Office, www.unglobalcompact.org/ docs/ news_events/8.1/PRME.pdf.

GRI Standards (2013). https://www.globalreporting. org/standards.

Jastrzębska E. (2015). „Środowisko przyrodnicze jako niemy interesariusz społecznie odpowiedzialnego przedsiębiorstwa. Dobre praktyki biznesu w Polsce", Logistyka Odzysku, nr 2(15), s. 49-51. i próba wskazania wytycznych dla opracowania raportów CSR. Wytyczne te powinny być oparte na badaniach empirycznych interesariuszy wewnętrznych i zewnętrznych oraz dobrych praktykach uczelni zagranicznych.

Koneczna R. (2014). CSR i jego narzędzia jako element strategii firm - praktyczny przewodnik. Kraków: Wydawnictwo IGSMiE PAN.

Kowalski R. (2016). „Społeczna odpowiedzialność biznesu - perspektywa krytyczna", Zeszyty Naukowe Uniwersytetu Ekonomicznego w Krakowie, nr 5(953), s. 71-88.

Leja K. (2013). Zarządzanie uczelnią: Koncepcje i współczesne wyzwania. Warszawa: Wolters Kluwer.

Lo C.WH., Pang R.X., Egri C.P., Li P.H.Y. (2017). „University Social Responsibility: Conceptualization and an Assessment Framework", w: D. Shek, R. Hollister (red.), University Social Responsibility and Quality of Life. Quality of Life in Asia, tom 8. Singapur: Springer.

McGuire J.W. (1963). Business and society. New York: McGraw-Hill.

Nejati M., Shafaei A., Salamzadeh Y., Daraei M. (2011). "Corporate social responsibility and universities: A study of top 10 world universities' websites", African Journal of Business Management, vol. 5, no. 2, s. 440-447.

Odnowiona strategia Unii Europejskiej na lata 2011-2014 dotycząca Społecznej Odpowiedzialności Przedsiębiorstw (2011). Komunikat Komisji Europejskiej, COM (2011) 681.

OECD (2011). Wytyczne OECD dla przedsiębiorstw wielonarodowych. OECD Publishing, https://www.miir. gov.pl/media/40648/wytyczne_oecd.pdf.

Pędziwiatr E., Czaplicka-Kotas A., Kulczycka J. (2018). "Aspekty środowiskowe społecznej odpowiedzialności uczelni", Aura, nr 5, s. 16-17.

Płonka M. (2015). „Ekonomia społeczna a koncepcja polityki społecznej państwa. Model polski", Ekonomia Społeczna, nr 2, s. 85-100.

Raport Społeczny 2012-2014 (2014). Wydział Informatyki i Komunikacji Uniwersytetu Ekonomicznego w Katowicach, https://www.ue.katowice.pl/ fileadmin/_migrated/content_uploads/raport_spoleczny_Wlik_lipiec2014.pdf.

Shek D.T.L., Yuen-Tsang A.W.K., Ng E.C.W. (2017a). "University Social Responsibility (USR): Insight from the Historical Roots to the Contemporary Challenges", w: D. Shek, R. Hollister (red.), University Social Responsibility and Quality of Life. Quality of Life in Asia, tom 8. Singapur: Springer. DOI: 10.1007/978-981-103877-8_3.

Shek D.T.L., Yuen-Tsang A.W.K., Ng E.C.W. (2017b). „USR Network: A Platform to Promote University Social Responsibility", w: D. Shek, R. Hollister 
(red.), University Social Responsibility and Quality of Life. Quality of Life in Asia, tom 8. Singapur: Springer. DOI:10.1007/978-981-10-3877-8_2.

Sprawozdanie Rektora Akademii Górniczo-Hutniczej im. Stanisława Staszica w Krakowie z działalności uczelni w 2016 r. (2017). https://www. agh.edu.pl/fileadmin/default/templates/images/ Aktualnosci/aktualnosci/_2017/0630/Sprawozdanie_ wladz_AGH_2016.pdf (dostęp: 15.12.2017).

Sznajder M. (2013). „Korzyści z wdrożenia koncepcji społecznej odpowiedzialności biznesu (z uwzględnieniem koncepcji interesariuszy)", Ekonomia i Zarzqdzanie, nr 2 (5), s. 194-211.

Vadi M., Haldma T. (2010). „Knowledge transfer through university-industry relations: Some aspects of organizational culture", Discussion on Estonian Economic Policy, vol. 18.

Vallaeys F. (2013). Defining social responsibility: a matter of philosophical urgency for university. Global University Network for Innovation, http://www. guninetwork.org/articles/defining-social-responsibility-matter-philosophical-urgency-universities.

Vasilescu R., Barna C., Epure M., Baicu C. (2010). „Developing university social responsibility: A model for the challenges of the new civil society", Procedia - Social and Behavioral Sciences, vol. 2, iss. 2, s. 41774182.

Wigmore-Álvarez A., Ruiz-Lozano M. (2012). "University Social Responsibility (USR) in the Global Context: An Overview of Literature", Business \& Professional Ethics Journal, vol. 31, no. 3-4, s. 475-498. DOl: 10.5840/bpej2012313/424

Wilson C. (2016). "CSR Reporting and the University", Honors College Capstone Experience/Thesis Projects, Paper 638, https://digitalcommons.wku.edu/cgi/ viewcontent.cgi?article $=1645 \&$ context=stu_hon_ theses.

\section{Strony internetowe: \\ www.agh.edu.pl www.cam.ac.uk. www.ed.ac.uk. www.green.harvard.eu www.le.ac.uk. www.sustainable.stanford.edu www.sustainable.yale.edu}

\section{Social responsibility activities of higher education institutions - good practices}

Summary: An implementation of the knowledge economy influence on changes in higher education. A significant element of the concept is introducing an effective knowledge management mechanism, which lead to greater competitiveness and innovation of the university in both a Polish and international context. Therefore in the university's strategic areas of action it is necessary to present not only scientific achievements but also social, ecological and economic factors in the form of social reports, in accordance with the concept of social responsibility and new role of universities as the organizations serving its environment. There are many examples of good practices developed by foreign universities, which interpret the university social responsibility in a different way, depending on their development strategies. So far social responsibility report has not been published by any Polish technical university. The aim of the article is to review the university social responsibility practices in the foreign universities as well as to present the stages of social responsibility reporting in the technical university on the example of AGH University of Science and Technology. The article states that AGH has developed significant number of good practices in social responsibility, which have not yet been presented in the form of social report.

Keywords: CSR, USR, social reporting, sustainable development.

\section{Prawa autorskie i licencja / Copyright and License}

Artykuł opublikowano na licencji Creative Commons

Uznanie autorstwa - Użycie niekomercyjne - Bez utworów zależnych 3.0 Polska http://creativecommons.org/licenses/by-nc-nd/3.0/pl/

This article is published under the terms of the Creative Commons Attribution - NonCommercial - NoDerivs (CC BY-NGND 3.0) License http://creativecommons.org/licenses/by-nc-nd/3.0/ 